\title{
Depression, Anxiety and Quality of Life of Family Caregivers of Patients with Type 2 Diabetes
}

\author{
Inan Anaforoğlu ${ }^{a}$ İbrahim Ramazanoğulları ${ }^{b}$ Ekrem Algün ${ }^{a}$ Remzi Kutanis ${ }^{c}$ \\ Departments of ${ }^{a}$ Endocrinology and Metabolism, ${ }^{b}$ Family Medicine and ${ }^{c}$ Psychiatry, Trabzon Numune Education \\ and Research Hospital, Trabzon, Turkey
}

\section{Key Words}

Type 2 diabetes · Depression • Family caregiver • Quality of life

\begin{abstract}
Objective: It was our aim to investigate the quality of life (QOL) among family caregivers of patients with type 2 diabetes mellitus. Subjects and Methods: The Short Form-36 QOL scale, Beck Depression Inventory and State-Trait Anxiety Inventory Form were used to evaluate the presence and degree of depression and anxiety and their association with sociodemographic features of 50 family caregivers of diabetic patients compared to 54 controls. Results: The groups were similar in terms of age, sex, health insurance, educational status and marital and financial status. Beck Depression Inventory scores were significantly higher in family caregivers ( $p=0.001$ ) than in controls. Depression as a categorical variable was significantly more frequent among family caregivers of diabetic patients than among controls $(p<$ 0.001). The social function component of the QOL of controls was better than that of family caregivers $(p<0.005)$. There
\end{abstract}

\section{KARGER}

Fax +4161306 1234

E-Mail karger@karger.ch

www.karger.com
() 2011 S. Karger AG, Basel

$1011-7571 / 12 / 0214-0360 \$ 38.00 / 0$

Accessible online at:

www.karger.com/mpp was no difference between groups in terms of anxiety. Conclusion: Family caregivers of diabetic patients appeared to be more prone to depression and tended to have a poorer QOL.

Copyright $\odot 2011$ S. Karger AG, Basel

\section{Introduction}

Chronic diseases such as diabetes are commonly associated with depression and deterioration in quality of life (QOL) [1]. For example, in one study, examining the impact of depressive and chronic physical conditions such as diabetes on functional status and health care use, patients with chronic physical illness and comorbid depression had increased functional disability, used healthcare services more frequently, and were absent from work more often than patients who had chronic physical illnesses without comorbid depression [2].

The association between diabetes and depression has been extensively analyzed [1,3-5]. There are many controlled studies demonstrating the increased prevalence of 
depression in patients with type 2 diabetes mellitus $[1,5]$. The prevalence of depression in patients with diabetes ranges between 9 and 26\% [1]. Recent studies also showed that depression may constitute a major risk factor in the development of type 2 diabetes mellitus and may accelerate the onset of diabetic complications $[1,5]$. Diabetes can cause blindness, kidney failure and neuropathy as well as atherosclerosis that can lead to stroke or myocardial infarction, all ultimately associated with increased mortality [6] in addition to a poorer QOL $[7,8]$.

Factors affecting QOL in diabetic patients include depression, sexual dysfunction, comorbid medical conditions, complications of diabetes, and the quality of family relationships [7-10]. On a daily basis, patients must closely monitor and adjust their diets, test their blood glucose levels, take medication, and exercise. These tasks are largely done within the family setting, which directly and indirectly influences both the patients and their family members. Social support - assistance and protection given to others, especially to individuals - has been shown to improve disease management among adults with diabetes $[11,12]$.

The World Health Organization has stated that 'health care for chronic conditions must be oriented around the patient and the family' [13], given that chronic disease affects the QOL of both family caregivers and patients [14]. Unfortunately, few studies have assessed the QOL of family caregivers of diabetic patients [15-17]. Those that have examined this issue have clearly stated that clinicians should be aware of the caregivers' position [15-17]. In this study, we aimed to assess the QOL among family caregivers of patients with type 2 diabetes versus controls, by evaluating their state of depression and anxiety and determining their association with sociodemographic features.

\section{Subjects and Methods}

\section{Subjects}

Family members of 50 patients with type 2 diabetes mellitus, of whom each had been followed for at least 6 months in our outpatient clinic, were recruited for the study. Patients were all adults. They were randomly chosen from the records of the endocrinology clinic by simple random sampling method and contacted by telephone for interviewing. Sixty-four caregivers were called: 5 of them did not answer and 9 did not accept to come to the hospital for the interview.

Inclusion criteria were: caregivers living in the same house with the patient, responsible for helping with treatment of the patient, being an adult, and having the ability to understand and answer the interview questions. Exclusion criteria were: any chronic disease, any previously diagnosed mental illness, use of any psychiatric medication, or any physical disability that could prevent the subject from helping the patient.

Controls were chosen from among natives living in the same locale with no physical or mental illness. They were chosen from among healthy relatives of the hospital staff. Hospital staff were informed about the study and were encouraged to invite their healthy relatives to participate in the study. Controls were matched with test patients with regard to educational, socioeconomic, occupational and marital status.

Each participant was informed about the purpose of the study before the interview, and they had the right to refuse to participate and withdraw at any time. All participants signed an informed consent document to participate in the study, which was conducted with the approval of the Ethics Committee, Trabzon Numune Education and Research Hospital, Trabzon, Turkey. Questionnaires in Turkish language were administered face-to-face and completed in about $30-45 \mathrm{~min}$ by the same physician (İ.R.).

\section{Methods}

Short Form-36 QOL Questionnaire. The participant's health status was evaluated by using the Short Form (SF)-36 questionnaire, Turkish version $[18,19]$. It consists of 36 questions measuring 8 health concepts: physical function, role physical, bodily pain, general health, vitality, social function, role emotional, and mental health. The scoring was conducted upon a scale of $0-100$, with higher scores reflecting better health status.

Beck Depression Inventory. The Beck Depression Inventory (BDI) is a reliable, easy-to-use screening instrument that has been applied worldwide in both psychiatric and non-psychiatric populations [20]. The Turkish version of the BDI was validated by Hisli [21], with a Cronbach $\alpha$ reliability of 0.8 . It comprises 21 items to measure the severity of depressive symptoms. Each item is scored on a scale of $0-3$, with total scores ranging from 0 to 63 (normal, 0-9; mild to moderate depression, 10-18; moderate to severe depression, 19-29; and severe depression, 30-63) [20].

State-Trait Anxiety Inventory Form. The State-Trait Anxiety Inventory (STAI) is a self-report measure that assesses trait (20 questions) and state of anxiety (20 questions). The temporary condition of 'state anxiety' (STAI-TX1) and the more general and longstanding quality of 'trait anxiety' (STAI-TX2) are clearly differentiated by assessing how respondents feel 'right now' and assessing anxiety proneness or how respondents 'feel generally' [22]. It has been validated for the Turkish population by Öner and Le Compte [23].

\section{Statistical Analysis}

The SPSS software (version 16.0, SPSS Inc., Chicago, Ill., USA) was used for statistical analyses. Data normality was assessed by the Kolmogorov-Smirnov test. Comparisons between groups were done with the Student $t$ test for normally distributed data and with the Mann-Whitney $U$ test for non-normally distributed data. Categorical variables were analyzed by the $\chi^{2}$ test, and oneway ANOVA was used to evaluate the differences between the groups for continuous variables. Frequencies and percentages were used to summarize nominal data; standard deviations were used to summarize continuous data. 
Table 1. Sociodemographic characteristics of the participants

\begin{tabular}{|c|c|c|c|c|c|}
\hline & \multicolumn{2}{|c|}{$\begin{array}{l}\text { Family } \\
\text { caregivers } \\
(\mathrm{n}=50)\end{array}$} & \multicolumn{2}{|c|}{$\begin{array}{l}\text { Controls } \\
(\mathrm{n}=54)\end{array}$} & \multirow[t]{2}{*}{$\mathrm{p}$} \\
\hline & $\mathrm{n}$ & $\%$ & $\mathrm{n}$ & $\%$ & \\
\hline Age group & & & & & 0.998 \\
\hline $18-29$ years & 10 & 20 & 10 & 18.5 & \\
\hline $30-34$ years & 10 & 20 & 10 & 18.5 & \\
\hline $35-39$ years & 3 & 6 & 3 & 5.6 & \\
\hline $40-44$ years & 15 & 30 & 17 & 31.5 & \\
\hline $45-49$ years & 12 & 24 & 14 & 25.6 & \\
\hline Sex, female & 35 & 70 & 39 & 72.2 & 0.973 \\
\hline Married & 39 & 78 & 43 & 79.6 & 1.000 \\
\hline Educational status & & & & & 0.187 \\
\hline Primary school & 19 & 38 & 12 & 22.2 & \\
\hline Secondary/high school & 21 & 42 & 26 & 48.2 & \\
\hline University & 10 & 20 & 16 & 29.6 & \\
\hline Occupational status & & & & & 0.063 \\
\hline Housewife & 20 & 40 & 14 & 25.9 & \\
\hline Officer & 5 & 10 & 15 & 27.8 & \\
\hline Laborer/worker & 6 & 12 & 11 & 20.4 & \\
\hline Self-employed & 8 & 16 & 9 & 16.7 & \\
\hline Retired & 2 & 4 & 2 & 3.7 & \\
\hline Unemployed & 9 & 18 & 3 & 0.6 & \\
\hline Assurance & & & & & 0.546 \\
\hline Social security institution & 11 & 22.4 & 16 & 29.6 & \\
\hline Retirement fund & 39 & 77.6 & 38 & 70.4 & \\
\hline Monthly income & & & & & 0.070 \\
\hline $\mathrm{YTL} \leq 500$ & 3 & 6 & 0 & 0 & \\
\hline YTL 500-1,000 & 24 & 48 & 16 & 29.6 & \\
\hline YTL 1,000-1,500 & 7 & 14 & 14 & 25.9 & \\
\hline YTL 1,500-2,000 & 8 & 16 & 10 & 18.6 & \\
\hline YTL $>2,000$ & 8 & 16 & 14 & 25.9 & \\
\hline
\end{tabular}

1 YTL (New Turkish Lira) $=0.54$ USD.

Table 2. Distribution of QOL scores

$\begin{array}{ll}\begin{array}{l}\text { Family caregivers } \\ (\mathrm{n}=50)\end{array} & \begin{array}{l}\text { Controls } \\ (\mathrm{n}=54)\end{array}\end{array}$

\begin{tabular}{lllr}
\hline SF-36 & & & \\
$\quad$ Physical function & $78.0 \pm 21.0$ & $84.4 \pm 16.7$ & 0.089 \\
Role physical & $63.0 \pm 40.2$ & $76.9 \pm 32.5$ & 0.088 \\
Bodily pain & $67.2 \pm 24.0$ & $71.8 \pm 21.6$ & 0.307 \\
General health & $54.4 \pm 15.8$ & $61.7 \pm 23.7$ & 0.067 \\
Vitality & $52.6 \pm 16.4$ & $57.4 \pm 24.5$ & 0.239 \\
Social function & $59.8 \pm 23.3$ & $76.4 \pm 21.3$ & $<0.005$ \\
Role emotional & $56.7 \pm 45.8$ & $73.5 \pm 36.8$ & 0.069 \\
Mental health & $55.9 \pm 11.3$ & $60.9 \pm 20.0$ & 0.114 \\
BDI & $13.8 \pm 9.9$ & $7.8 \pm 7.5$ & 0.001 \\
STAI-TX1 & $44.9 \pm 4.5$ & $45.2 \pm 3.7$ & 0.637 \\
STAI-TX2 & $44.8 \pm 5.7$ & $44.6 \pm 4.4$ & 0.896 \\
\hline
\end{tabular}

Values are expressed as means \pm SDs.

\section{Results}

Sociodemographic characteristics of the participants are presented in table 1 . The characteristics of the groups showed no significant differences. Of the 50 caregivers, 25 were daughters, 13 spouses and 12 sons.

The QOL scores were generally lower among caregivers compared with controls, but differences were not significant for components of the SF-36 except for social function (table 2). In contrast, BDI scores were significantly higher in family caregivers than in controls $(\mathrm{p}=0.001)$. Depressive symptoms (BDI score $\geq 10$ ) were present in $64 \%$ of caregivers versus only $27.8 \%$ of controls $(\mathrm{p}<0.001)$. Values for STAI-TX1 and STAI-TX2 scores did not differ significantly between the two groups (table 2).

All SF-36 component scores, and the STAI-TX2 score, were significantly lower among women in the caregiver group except for role emotional (table 3). The physical function component score was lower among married (75 $\pm 22)$ than among single $(86.6 \pm 17.5)$ caregivers but the difference was of borderline significance ( $p=0.057$; table 3). Controls did not show any significant differences by sex, relationship type or employment situation. The single controls did have a significantly lower general health component score than the married controls (47.2 \pm 28 vs. $65.4 \pm 21.2 ; \mathrm{p}=0.021$ ). Physical function, bodily pain, general health and vitality component scores were also significantly lower among unemployed caregivers (table 4). In addition, the social function and mental health component scores were significantly lower among daughter caregivers than among son or spouse caregivers, but not those for depression or anxiety (table 5). All but two of the component scores (role physical, role emotional) were significantly lower in subjects who had less than a secondary school education (table 6), but depression and anxiety scores did not differ significantly.

\section{Discussion}

Family caregivers had a greater risk of depression than controls, confirming and extending previous work in this area [15-17].

For SF-36, a specific indicator of QOL, no significant difference, except social function, was observed between caregivers and controls, although all scores were lower in caregivers than in controls. The BDI scores, which indicate depressive state, were significantly higher in caregivers than in controls. Equally important, the prevalence of depression (BDI score $\geq 10$ ) was significantly higher 
Table 3. QOL scores by sex and marital status

\begin{tabular}{|c|c|c|c|c|c|c|}
\hline & \multicolumn{3}{|c|}{ Family caregivers $(\mathrm{n}=50)$} & \multicolumn{3}{|c|}{ Family caregivers $(\mathrm{n}=50)$} \\
\hline & females $(n=35)$ & males $(n=15)$ & $\mathrm{p}$ & married $(n=39)$ & single $(n=11)$ & $\mathrm{p}$ \\
\hline \multicolumn{7}{|l|}{ SF-36 } \\
\hline Physical function & $74.0 \pm 22.5$ & $87.3 \pm 13.6$ & 0.014 & $75.0 \pm 2.2$ & $88.6 \pm 17.5$ & 0.057 \\
\hline Role physical & $54.3 \pm 41.3$ & $83.3 \pm 29.4$ & 0.019 & $61.5 \pm 40.1$ & $68.2 \pm 41.9$ & 0.554 \\
\hline Bodily pain & $62.4 \pm 23.8$ & $78.5 \pm 21.4$ & 0.024 & $65.3 \pm 22.5$ & $78.5 \pm 21.3$ & 0.294 \\
\hline General health & $51.2 \pm 15.4$ & $61.8 \pm 14.5$ & 0.028 & $53.2 \pm 15.4$ & $58.5 \pm 17.2$ & 0.329 \\
\hline Vitality & $49.0 \pm 15.4$ & $61.0 \pm 15.9$ & 0.016 & $51.7 \pm 15.4$ & $55.9 \pm 19.9$ & 0.454 \\
\hline Social function & $53.9 \pm 22.6$ & $73.3 \pm 19.4$ & 0.006 & $58.3 \pm 22.8$ & $64.8 \pm 25.5$ & 0.338 \\
\hline Role emotional & $48.6 \pm 46.7$ & $75.6 \pm 38.8$ & 0.051 & $55.6 \pm 46.1$ & $60.6 \pm 46.7$ & 0.656 \\
\hline Mental health & $52.5 \pm 9.9$ & $64.0 \pm 10.5$ & 0.001 & $55.1 \pm 10.6$ & $58.9 \pm 13.8$ & 0.327 \\
\hline BDI & $15.4 \pm 10.4$ & $9.9 \pm 6.3$ & 0.06 & $14.7 \pm 9.9$ & $10.3 \pm 8.4$ & 0.179 \\
\hline STAI-TX1 & $45.6 \pm 4.8$ & $43.2 \pm 3.2$ & 0.087 & $45.1 \pm 4.6$ & $43.9 \pm 4.1$ & 0.433 \\
\hline STAI-TX2 & $45.8 \pm 5.3$ & $42.3 \pm 5.9$ & 0.041 & $44.8 \pm 6.1$ & $44.5 \pm 4.3$ & 0.842 \\
\hline
\end{tabular}

Values are expressed as means \pm SDs.

Table 4. QOL scores by employment status

\begin{tabular}{|c|c|c|c|c|c|c|}
\hline & \multicolumn{3}{|c|}{ Family caregivers $(\mathrm{n}=50)$} & \multicolumn{3}{|c|}{ Controls $(\mathrm{n}=54)$} \\
\hline & $\begin{array}{l}\text { employed } \\
(\mathrm{n}=19)\end{array}$ & $\begin{array}{l}\text { unemployed } \\
(\mathrm{n}=31)\end{array}$ & $\mathrm{p}$ & $\begin{array}{l}\text { employed } \\
(\mathrm{n}=35)\end{array}$ & $\begin{array}{l}\text { unemployed } \\
(\mathrm{n}=19)\end{array}$ & $\mathrm{p}$ \\
\hline \multicolumn{7}{|l|}{ SF-36 } \\
\hline Physical function & $85.5 \pm 15.4$ & $73.4 \pm 22.8$ & 0.030 & $84.6 \pm 18.6$ & $83.9 \pm 20.1$ & 0.882 \\
\hline Role physical & $75.0 \pm 34.4$ & $55.6 \pm 42.2$ & 0.084 & $91.4 \pm 36.9$ & $86.8 \pm 19.3$ & 0.298 \\
\hline Bodily pain & $78.5 \pm 21.4$ & $60.3 \pm 23.3$ & 0.006 & $82.8 \pm 22.6$ & $69.9 \pm 20$ & 0.664 \\
\hline General health & $62.2 \pm 16.9$ & $49.6 \pm 13.2$ & 0.005 & $68.6 \pm 25.6$ & $67.4 \pm 18.9$ & 0.195 \\
\hline Vitality & $60.3 \pm 14.7$ & $47.9 \pm 15.8$ & 0.008 & $57.9 \pm 22.4$ & $56.6 \pm 28.6$ & 0.857 \\
\hline Social function & $63.8 \pm 22.0$ & $57.3 \pm 24.1$ & 0.340 & $84.6 \pm 21.3$ & $79.6 \pm 21.3$ & 0.418 \\
\hline Role emotional & $70.2 \pm 42.9$ & $48.4 \pm 46.2$ & 0.091 & $81.4 \pm 40.5$ & $77.2 \pm 29.5$ & 0.992 \\
\hline Mental health & $59.2 \pm 10.6$ & $53.9 \pm 11.4$ & 0.114 & $62.7 \pm 16.8$ & $57.7 \pm 25.1$ & 0.380 \\
\hline BDI & $13.3 \pm 9.5$ & $14.1 \pm 9.9$ & 0.780 & $7.9 \pm 8.2$ & $7.6 \pm 6.4$ & 0.886 \\
\hline STAI-TX1 & $44.5 \pm 4.1$ & $45.1 \pm 4.8$ & 0.685 & $45.7 \pm 3.9$ & $44.3 \pm 2.9$ & 0.177 \\
\hline STAI-TX2 & $44.5 \pm 5.9$ & $44.2 \pm 5.6$ & 0.784 & $45.5 \pm 4.3$ & $43.1 \pm 4.3$ & 0.061 \\
\hline
\end{tabular}

Values are expressed as means \pm SDs.

among caregivers compared to controls, as shown in previous studies $[14,24]$.

Similar to most studies [15, 25-27], the majority of caregivers in our study were women and spouses. Female caregivers, a daughter or spouse, generally had lower QOL and STAI scores, but higher BDI scores, as previously reported by Li et al. [28]. These indices are a reflection of the fact that in the traditional family setting such as in our country, women generally have more responsibility in taking care of the family including the sick, even if working outside the home. Marital status did not appear to be significantly associated with QOL, depression or anxiety scores among caregivers because all scores for single caregivers were better than those for married caregivers, possibly because married people may have less time for themselves and more responsibilities.

In the caregiver group, those who were employed or had a higher education had a significantly better QOL than the umemployed and less educated. This may be because working outside home may have a protective effect 
Table 5. QOL scores by type of caregiver relationship

\begin{tabular}{lllll}
\hline & $\begin{array}{l}\text { Daughter } \\
(\mathrm{n}=25)\end{array}$ & $\begin{array}{l}\text { Son } \\
(\mathrm{n}=13)\end{array}$ & $\begin{array}{l}\text { Spouse } \\
(\mathrm{n}=12)\end{array}$ & $\mathrm{p}$ \\
\hline SF-36 & & & & \\
$\quad$ Physical function & $76.6 \pm 22.9$ & $88.1 \pm 14.5$ & $70.0 \pm 20.1$ & 0.087 \\
$\quad$ Role physical & $58.0 \pm 38.7$ & $84.6 \pm 29.8$ & $50.0 \pm 46.5$ & 0.064 \\
Bodily pain & $62.8 \pm 25.5$ & $79.2 \pm 22.9$ & $63.3 \pm 18.7$ & 0.110 \\
$\quad$ General health & $52.5 \pm 13.6$ & $61.5 \pm 13.8$ & $50.7 \pm 20.3$ & 0.158 \\
$\quad$ Vitality & $49.6 \pm 15.2$ & $59.2 \pm 16.4$ & $51.7 \pm 18.0$ & 0.226 \\
$\quad$ Social function & $54.5 \pm 24.2$ & $75.0 \pm 19.8$ & $54.2 \pm 18.7$ & 0.020 \\
$\quad$ Role emotional & $52.5 \pm 9.9$ & $71.8 \pm 40.5$ & $55.3 \pm 11.7$ & 0.388 \\
$\quad$ Mental health & $52.8 \pm 9.4$ & $63.1 \pm 10.9$ & $64.4 \pm 12.3$ & 0.020 \\
BDI & $14.5 \pm 10.2$ & $9.8 \pm 6.8$ & $16.5 \pm 10.6$ & 0.202 \\
STAI-TX1 & $44.9 \pm 4.5$ & $43.2 \pm 3.2$ & $46.7 \pm 5.3$ & 0.149 \\
STAI-TX2 & $46.2 \pm 4.9$ & $42.7 \pm 5.5$ & $43.9 \pm 6.8$ & 0.160 \\
\hline
\end{tabular}

Values are expressed as means \pm SDs.
Table 6. QOL scores by education status

$\begin{array}{llll}\text { Illiterate/pri- Secondary/ } & \text { University } & \mathrm{p} \\ \text { mary school } & \begin{array}{l}\text { high school } \\ (\mathrm{n}=19)\end{array} & (\mathrm{n}=21) & (\mathrm{n}=10)\end{array}$

SF-36

Physical function $66.8 \pm 22.5 \quad 81.2 \pm 18.9 \quad 92.5 \pm 8.9 \quad 0.003$

$\begin{array}{lllll}\text { Role physical } & 48.7 \pm 44.5 & 70.2 \pm 35.0 & 75.0 \pm 37.3 & 0.136\end{array}$

$\begin{array}{lllll}\text { Bodily pain } \quad 57.4 \pm 21.9 & 67.3 \pm 24.3 & 85.7 \pm 17.1 & 0.008\end{array}$

General health $\quad 47.0 \pm 14.0 \quad 53.3 \pm 12.1 \quad 70.7 \pm 15<0.005$

$\begin{array}{lllll}\text { Vitality } & 44.7 \pm 12.1 & 51.9 \pm 16.9 & 69.0 \pm 9.9 & <0.005\end{array}$

$\begin{array}{lllll}\text { Social function } \quad 53.9 \pm 22.8 & 54.8 \pm 21.8 & 81.3 \pm 14.7 & 0.003\end{array}$

$\begin{array}{lllll}\text { Role emotional } & 43.9 \pm 47.2 & 58.7 \pm 44.6 & 76.7 \pm 41.7 & 0.197\end{array}$

$\begin{array}{lllll}\text { Mental health } \quad 52.8 \pm 9.4 & 54.7 \pm 10.9 & 64.4 \pm 12.3 & 0.023\end{array}$

$\begin{array}{lllll}\text { BDI } & 14.4 \pm 8.0 & 14.9 \pm 10.9 & 10.1 \pm 9.8 & 0.410\end{array}$

$\begin{array}{lllll}\text { STAI-TX1 } & 45.0 \pm 4.9 & 45.0 \pm 4.8 & 44.2 \pm 3.0 & 0.878\end{array}$

$\begin{array}{lllll}\text { STAI-TX2 } & 45.1 \pm 6.4 & 44.6 \pm 6.1 & 44.5 \pm 3.1 & 0.878\end{array}$

Values are expressed as means \pm SDs. on the caregivers. Caregivers with a higher income also had better scores (data not shown). Many other studies have noted a similar association between educational status and income $[14,15,25]$.

In our study, it has been clearly shown that caregivers of patients with type 2 diabetes mellitus were depressed, but not anxious, and although all scores favored controls, the QOL of caregivers is not impaired statistically except for social function. SF-36 asks how subjects felt during the past 4 weeks and the status during this period. Higher or lower scores may be affected by events having occurred during this time. We hope this will be evaluated in future studies.

Our study has two main limitations. First, we did not assess the effect of diabetes complications on the caregiv- ers' QOL or depressive state. Second, the present study was performed cross-sectionally in a relatively small group from a single center. Therefore, our findings may not represent those of a broader population.

In conclusion, diabetes mellitus affected the QOL of the family caregivers, and caregivers of patients with type 2 diabetes tended to be more depressed.

\section{Acknowledgements}

We thank our diabetes education nurse, Miss Nurşen Arslan, for her assistance in telephoning our registered patients and their caregivers. We also thank our patients and their families for the perfect collaboration.

\section{References}

1 Musselman DL, Betan E, Larsen H, Phillips LS: Relationship of depression to diabetes types 1 and 2: epidemiology, biology and treatment. Biol Psychiatry 2003;54:317-329.

-2 Stein MB, Cox BJ, Afifi TO, Belik SL, Sareen $\mathrm{J}$ : Does co-morbid depressive illness magnify the impact of chronic illness? A populationbased perspective. Psychol Med 2006;36: 587-596.

-3 Tuncay T, Musabak I, Gok ED, Kutlu M: The relationship between anxiety, coping strategies and characteristics of patients with diabetes. Health Qual Life Outcomes 2008;6:79.
4 Saglam AZ, Saler T, Erdem TY, Ataoglu E, Temiz LU, Yenigun M: The frequency of depression in Turkish patients with diabetes and diabetic complications. Endocrinologist 2010;20:19-22.

5 Astle F: Diabetes and depression: a review of the literature. Nurs Clin North Am 2007;42: 67-78.

6 6 The DECODE Study Group: Is fasting glucose sufficient to define diabetes? Epidemiological data from 20 European studies. European Diabetes Epidemiology Group. Diabetes epidemiology: collaborative analysis of diagnostic criteria in Europe. Diabetologia 1999;42:647654 .
-7 Glasgow RE, Ruggierio L, Eakin EG, Dryfood J, Chobanian L: Quality of life and associated characteristics in a large national sample of adults with diabetes. Diabetes Care 1997;20:562-567.

8 Peyrot M, Rubin RR: Levels and risks of depression and anxiety symptomatology among diabetic adults. Diabetes Care 1997; 20:585-590.

$\checkmark 9$ Trief PM, Wade MJ, Britton KD, Weinstock PS: A prospective analysis of marital relationship factors and quality of life in diabetes. Diabetes Care 2002;25:1154-1158. 
10 Grey M, Boland EA, Yu C, Sullivan-Bolyai S, Tamborlane WV: Personal and family factors associated with quality of life in adolescents with diabetes. Diabetes Care 1998;21: 909-914.

11 Miller CK, Davis MS: The influential role of social support in diabetes management. Top Clin Nutr 2005;20:157-165.

12 Cole I, Chesla CA: Interventions for the family with diabetes. Nurs Clin North Am 2006; 41:625-639.

13 World Health Organization: Innovative Care for Chronic Conditions: Building Blocks for Action. Geneva, World Health Organization, 2002.

14 Lim JW, Zebrack B: Caring for family members with chronic physical illness: a critical review of caregiver literature. Health Qual Life Outcomes 2004;2:1-9.

$\checkmark 15$ Awadalla AW, OhaeriJU, Al-Awadi SA, Tawfiq AM: Diabetes mellitus patients' family caregivers' subjective quality of life. J Natl Med Assoc 2006;98:727-736.
6 Awadalla AW, Ohaeri JU, Tawfiq AM, AlAwadi SA: Subjective quality of life of outpatients with diabetes: comparison with family caregivers' impressions and control group. Natl Med Assoc 2006;98:737-745.

17 Brod M: Quality of life issues in patients with diabetes and lower extremity ulcers: patients and caregivers. Qual Life Res 1998;7:365372.

18 Aydemir Ö, Köroğlu E: Psikiyatride Kul lanılan Klinik Ölçekler, Hekimler Yayın Birliği, Ankara, 2006.

19 Koçyiğit H, Aydemir O, Ölmez N, Memis A: Kisa Form 36 (KF-36)'nın Türkçe versiyonunun güvenilirliği ve geçerliliği. İlaç ve Tedavi Dergisi 1999;12:102-106.

20 Beck AT, Ward CH, Mendelson M, Mock J, Erbaugh J: An inventory for measuring depression. Arch Gen Psychiatry 1961;4:561571

21 Hisli N: Beck Depresyon Envanteri'nin geçerliliği üzerine bir çalışma. Psikoloji Dergisi 1988;6:18-122.

22 Spielberger CD, Edwards C, Mantoun J, Lushene R: The State-Trait Anxiety Inventory. Windsor, NFER-Nelson Press, 1987.
23 Öner N, Le Compte A: Handbook of StateTrait Anxiety. İstanbul, Bosphorus University Press, 1983.

24 Rees I, O’Boyle C, MacDonagh R: Quality of life: impact of chronic illness on the partner. J R Soc Med 2001;94:563-566.

25 Han B, Haley WE: Family caregiving for patients with stroke review and analysis. Stroke 1999;30:1478-1485.

26 Schulz R, Tompkins CA, Rau MT: A longitudinal study of the psychosocial impact of stroke on primary support persons. Psychol Aging 1988;3:131-141.

27 Haley WE, LaMonde LA, Han B, Burton AM, Schonwetter R: Predictors of depression and life satisfaction among spousal caregivers in hospice: application of a stress process model. J Palliat Med 2003;6:215-224.

28 Li TC, Li YD, Lin CC, Amidon RL: Quality of life of primary caregivers of elderly with cerebrovascular disease or diabetes hospitalized for acute care: assessment of well-being and functioning using the SF-36 health questionnaire. Qual Life Res 2004;13:1081-1088. 